\title{
The Impact of Leechiosis on Semi-Artificial Spawning Performance and Hematological Parameters of Silver Carp (Hypophthalmichthys Molitrix) Brooders and Common Carp (Cyprinus carpio) Fingerlings with A Reference to Its Stress Response and Treatment
}

\author{
Manal A. A. Essa ${ }^{1}$ (D), Fatma M.M. Korni ${ }^{1}$ (D, Walaa M. S. Ahmed ${ }^{2}$ (D)
}

Cite this article as: Essa, M.A.A., Korni, F.M.M., Ahmed, W.M.S. (2018). The Impact of Leechiosis on Semi-Artificial Spawning Performance and Hematological Parameters of Silver Carp (Hypophthalmichthys Molitrix) Brooders and Common Carp (Cyprinus carpio) Fingerlings with A Reference to Its Stress Response and Treatment. Aquatic Sciences and Engineering, 33(2): 53-60.

${ }^{2}$ Clinical Pathology, Faculty of Veterinary Medicine, Beni-Suef University, Beni-Suef 62511, Egypt

${ }^{1}$ Department of Fish Diseases and Management, Faculty of Veterinary Medicine, Beni-Suef University, BeniSuef 62511, Egypt

Submitted:

02.12.2017

Accepted:

23.03.2018

Correspondence:

Fatma M.M. Korni

E-mail:

naglaamostafa1@yahoo.com

(C) Copyright 2018 by Aquatic Sciences and Engineering

Available online at

dergipark.gov.tr/tjas

\begin{abstract}
There was a decrease in artificial spawning performance of hatchery-reared cyprinid brooders in the spring of 2016 in an Egyptian hatchery. In this study, cyprinid brooders and fingerlings were clinically examined in situ, which showed that they were affected with leechiosis. Hemiclepsis marginata were identified as a causative agent of leechiosis. The prevalence of leechiosis was highest in silver carp (Hypophthalmichthys molitrix) brooders and common carp (Cyprinus carpio) fingerlings. The infested brooders and fingerlings showed red to white marks, severe hemorrhages, and dark contracted worms on their skin. The impact of leechiosis on semi-artificial spawning performance and hematological parameters of $\mathrm{H}$. molitrix brooders was evaluated by determining the eggs weight, fertility, hatching percentage and the complete blood picture. Leechiosis had a significant impact on eggs weight, fertility, and hatching percentage. Microcytic hypochromic anemia, leukocytosis, lymphopenia, and heterophilia were recorded in the infested brooders. Regarding the association between leechiosis and stress response, the total antioxidant enzymes were found to be significantly decreased, whereas malondialdehyde levels were increased in the infested brooders compared with those in control samples. Under the experimental condition, leechiosis could be controlled among $C$. carpio fingerlings using trichlorfon, after which normal hematological parameters were recorded for the treated $C$. carpio fingerlings. Regarding the field conditions, trichlorfon could successfully control leechiosis in $\mathrm{H}$. molitrix brooders and $C$. carpio fingerlings.
\end{abstract}

Keywords: Leechiosis, Hemiclepsis marginata, Hypophthalmichthys molitrix, Cyprinus carpio, total antioxidant enzymes, malondialdehyde, trichlorfon

\section{INTRODUCTION}

Hatcheries confer many benefits to the aquaculture industry through, production of fries and fingerlings and genetic improvement to increase growth and survival of larvae and fries (Powell et al., 2002).

Cyprinids are the most commercially important group of cultured freshwater fish and are exploited for many purposes (Hoole et al., 2001). Silver carp (Hypophthalmichthys molitrix, H. molitrix) is a filter feeder, so, it used for controlling excessive growth of phytoplankton to keep good water quality in aquaculture (Ellender and Weyl, 2014).

Leechiosis has a worldwide distribution and it is the most important parasitic fish disease in the phylum Annelida (Woo, 2006). Leechiosis can potentially affect fish health through blood losing, hemorrhage, ulceration, inflammation, tissue damage, osmoregulatory failure and transmission of pathogenic blood parasites, some bacterial and viral diseases (Burreson, 2006; Koyun et al., 2015; Woo, 2006). Also, it causes mortality in fish hatcheries (Woo, 2006) because of large amounts of blood loss or sec- 
ondary effects of multiple feeding wounds. Thus, presence of leechiosis in commercial aquaculture should always be a cause for concern (Woo, 2006).

Some parasitic fish diseases have been recognized to affect the fecundity of brood stocks through causing stress (Dautremepuits et al., 2003). Stress is one of infertility causes (Wasser et al., 1993), so, poor response of brood stocks to artificial spawning occur (Akar, 2011).

Data reporting oxidative stress and lipid peroxidation associated with parasitic infestation in fish are few (Stumbo et al., 2012; Mozhdeganloo and Heidarpour, 2014).

Trichlorfon seems to be effective in the control of leechiosis under field conditions and repeated applications are required in ponds with reproducing leeches (Morrison et al., 1993). It has a low persistence in water and it is not bioconcentrated in fish lipids (Canadian Council of Ministers of the Environment, 2012). Additionally, it was transformed to dichlorvos which is hydrolyzed in water and showed little tendency to absorb by soil particles or bioconcentrate in plant and fish (Lopes et al., 2006).

By tracing the available literature, there is no investigation on the impact of leechiosis on the artificial spawning performance of cyprinid brooders. Thus, the aim of the present study was planned to evaluate the impact of leechiosis on semi-artificial spawning performance and hematological parameters of $H$. molitrix brooders. Therefore, the weight of eggs, fertility and hatching percentage and complete blood picture were determined. Also, for evaluation of leechiosis associated with stress response, stress indicators (total antioxidant enzymes and malondialdehyde, MDA) levels were estimated. In addition, trials for control of leechiosis among infested fingerlings and brooders were carried out by using trichlorfon.

\section{MATERIAL AND METHOD}

\section{Case History and the Study Area}

There was a decrease in artificial spawning performance of hatchery reared cyprinid brooders during April and May of 2016 in Abo-Saleh fish hatchery, Beni-Suef, Egypt. This situation is supplied with freshwater which is drawn from Nile river. Abo-Saleh fish hatchery was designed for artificial spawning of silver carp (Hypophthalmichthys molitrix, H. molitrix), grass carp (Ctenopharyngodon idella, C. idella) while, common carp (Cyprinus carpio, C. carpio) was naturally spawning. It supplies north Upper Egypt especially Beni-Suef and El-Fayum areas with fries and fingerling of cyprinids. The hatchery design consists of one gravel filter, 3 biological filters, the hall for artificial spawning and rearing of larvae till become fry. Moreover, there are rearing ponds for brooders and incubating ponds for fries till reach to fingerlings (General Authority for Fisheries Development of the Ministry of Agriculture, http://www.gafrd.org).

\section{Clinical and Parasitological Examination of Fish Samples}

A total of 180 brooders and 600 fingerlings of cultured cyprinids were randomly collected alive from Abo-Saleh fish hatchery, Beni-Suef, Egypt during April and May 2016. Each month, $90 \mathrm{H}$. molitrix, C. idella, and C. carpio brooders (30 of each species) and 300 fingerlings (100 of each species) were visually examined in situ according to Noga (2010). The examined H. molitrix, C. idella and $C$. carpio brooders and fingerlings were 2-5 kilogram, $\mathrm{kg}(27-35 \mathrm{~cm}), 60-150 \mathrm{gram}, \mathrm{gm}(12-18 \mathrm{~cm}), 2.500-6 \mathrm{~kg}(25-32$ $\mathrm{cm}), 40-130 \mathrm{gm}(11 \mathrm{~cm}-18 \mathrm{~cm}), 3-8 \mathrm{~kg}(25-39 \mathrm{~cm})$ and $60-150 \mathrm{gm}$ $(12-18 \mathrm{~cm})$ respectively. The clinical abnormalities and prevalence of the suspected disease were recorded. Also, leechiosis suspected cases were parasitologically examined. The suspected leech was collected by gently dislodging its caudal sucker with forceps and placing in a dish containing water. The external characters were examined before fixation in 7\% formalin (Woo, 2006). Staining and identification of the suspected parasite was performed according to Pritchard and Kruse (1982).

\section{Determination of the Impact of Leechiosis Suspected Disease on Semi-Artificial Spawning Performance of $H$. molitrix Brooders}

A total of 18 infested males and females $H$. molitrix brooders (9 each) and equal number of apparently healthy ones (2-5 kg, 27-35 cm) were semi-artificially spawned in the hatchery during May 2016. Three semi-artificially spawning processes were performed, each semi-artificially spawning process had 6 infested ( 3 males and 3 females) and 6 apparently healthy ( 3 males and 3 females) brooders. The weight of collected eggs was recorded. Also, the fertility and hatching percentage of each semi-artificial spawning process was estimated according to Gheyas et al., (2001) as follows:

Fertilization rate $=$ (Number of fertilized eggs/Total number of eggs) $\times 100$

Hatching rate $=($ Number of hatched eggs $($ larvae $) /$ Total number of eggs) $\times 100$

\section{Estimation of the Effect of Leechiosis Suspected Disease on Hematological Parameters of $\boldsymbol{H}$. molitrix Brooders}

At the end of three semi-artificial spawning processes, the infested and apparently healthy males and females $H$. molitrix brooders were anaesthetized by tricaine methane sulfonate (MS 222) for collection of blood from caudal veins with syringes moist with heparin as anticoagulant for determination of red blood cell (RBC) count, packed cell volume (PCV \%), hemoglobin ( $\mathrm{Hb}$ ) concentration, total white blood cell count (WBC) and differential leukocytic count. They were measured by routine procedures (Feldman et al., 2000). The mean cell volume (MCV) and mean corpuscular hemoglobin concentration (MCHC) were calculated mathematically (Dacie and Lewis 1966).

\section{Estimation of Stress Indicators (Total Antioxidant Enzymes and MDA) Levels in Serum of Semi-Artificial Spawned H. molitrix Brooders}

At the end of three semi-artificial spawning processes, the infested and apparently healthy males and females $H$. molitrix brooders were anaesthetized by tricaine methane sulfonate (MS 222) for collection of blood from caudal veins without anticoagulant for serum separation. The collected serum was stored at $-20{ }^{\circ} \mathrm{C}$ for estimation of total antioxidant enzymes according to the manufacture of the commercial test kits (Bio-diagnostic Company, Egypt) and MDA according to Ohkawa et al., (1979). 


\section{Control of Leechiosis Suspected Disease Among C. carpio Fingerlings by Trichlorfon}

A total of 100 apparently healthy $C$. carpio fingerlings with average body weight of 110-140 $\mathrm{g}$ and total length of $14-17 \mathrm{~cm}$ were transferred to the wet lab. of Fish Diseases and Management Department, Faculty of Veterinary Medicine, Beni-Suef University, Egypt for determination of 24 hours median lethal concentration $\left(\mathrm{LC}_{50}\right)$ of trichlorfon. They were acclimated for 14 days in fiberglass tank (400 L capacity). After that, they were redistributed into 10 groups in 10 glass aquaria of $70 \times 25 \times 40 \mathrm{~cm}$, supplied with chlorine-free tap water (water temperature $25 \pm 2^{\circ} \mathrm{C}, \mathrm{pH}=7 \pm 0.3$ ) and continuous aeration. The $1^{\text {st }}$ to $10^{\text {th }}$ group received trichlorfon (United Company for chemicals and medical preparations, Egypt) concentrations of zero (control), 10, 20, 30, 40, 50, 60, 70, 80 and $90 \mathrm{mg} / \mathrm{L}$ respectively. The $\mathrm{LC}_{50}$ was calculated according to Behrens and Kerber (1953) using the following formula:

24 hours $L C_{50}=$ largest dose which killed all fish $-\Sigma(A x B) / n$ For control of leechiosis suspected disease among $C$. carpio fingerlings by trichlorfon, a total of 20 infested $C$. carpio fingerlings and 10 apparently healthy one with body weight ranged from 115$150 \mathrm{~g}$ were used. They were divided into 3 groups (10 fish each), the first infested group received $0.33 \mathrm{mg} / \mathrm{L}$ trichlorfon (field dose), the second one was control positive with no treatment, while, the third apparently healthy group was control negative and received no treatment. The treated group exposed to the product for $48 \mathrm{hrs}$ water bath and after bath duration, the fish was transported to clean water. The severity of clinical abnormalities was evaluated just before treatment and at $7^{\text {th }}$ day after bath duration. The treatment products were applied in two regime, each regime included application of the products once weekly for 2 times (2 weeks).

\section{Determination of the Effect of Trichlorfon on Hematological Parameters of Treated $C$. carpio Fingerlings}

At the end of trichlorfon treatment, fish in all groups were anesthetized by tricaine methane sulfonate (MS 222) for blood collection, and complete blood pictures were done.

\section{Field Control of Leechiosis Suspected Disease Among $H$. molitrix Brooders and C. carpio Fingerlings in Abo-Saleh Fish Hatchery}

Trichlorfon was added to a pond of 10 carat with $1 \mathrm{~m}$ water depth and containing infested $\mathrm{H}$. molitrix brooders $(2-5 \mathrm{~kg}$ of weight, $27-35 \mathrm{~cm}$ of length). Also, trichlorfon was added to a pond of 18 carat with $80 \mathrm{~cm}$ water depth and having infested C. carpio fingerlings (65-150 gm of weight, $12-18 \mathrm{~cm}$ of length). The dose of trichlorfon was $1 / 3 \mathrm{gm} / \mathrm{m}^{3}$ for $48 \mathrm{hrs}$ water bath, then, the water was changed. The severity of disease clinical abnormalities was evaluated just before treatment and at $7^{\text {th }}$ day after bath duration. The trichlorfon application was repeated as previously mentioned and the severity of disease clinical abnormalities was evaluated at $7^{\text {th }}$ day after bath duration. The treated brooders and fingerlings were transferred to new ponds and complete drainage, drying and disinfection of the treated ponds were done.

\section{Ethics Committee}

The present study was approved by the BSU-IACUC (Beni-Suef Institutional Animal Care and Use Committee).

\section{Statistical Analysis}

The data were presented as mean \pm SEM. Statistical analysis was performed by using T- student test and analysis of variance (ANOVA) followed by Tukey test, using Graphpad prism 5 versions (software, Philadelphia, USA). Values of $p<0.05$ were regarded as significant. Results are expressed as mean \pm SEM.

\section{RESULT AND DISCUSSION}

\section{The Clinical Abnormalities, Prevalence and Parasitological Identification}

The infested $H$. molitrix brooders showed severe hemorrhages at caudal peduncle (Figure 1.a, b). There were inflamed pectoral fins and red inflamed marks at body sides (Figure 1c) and ven-
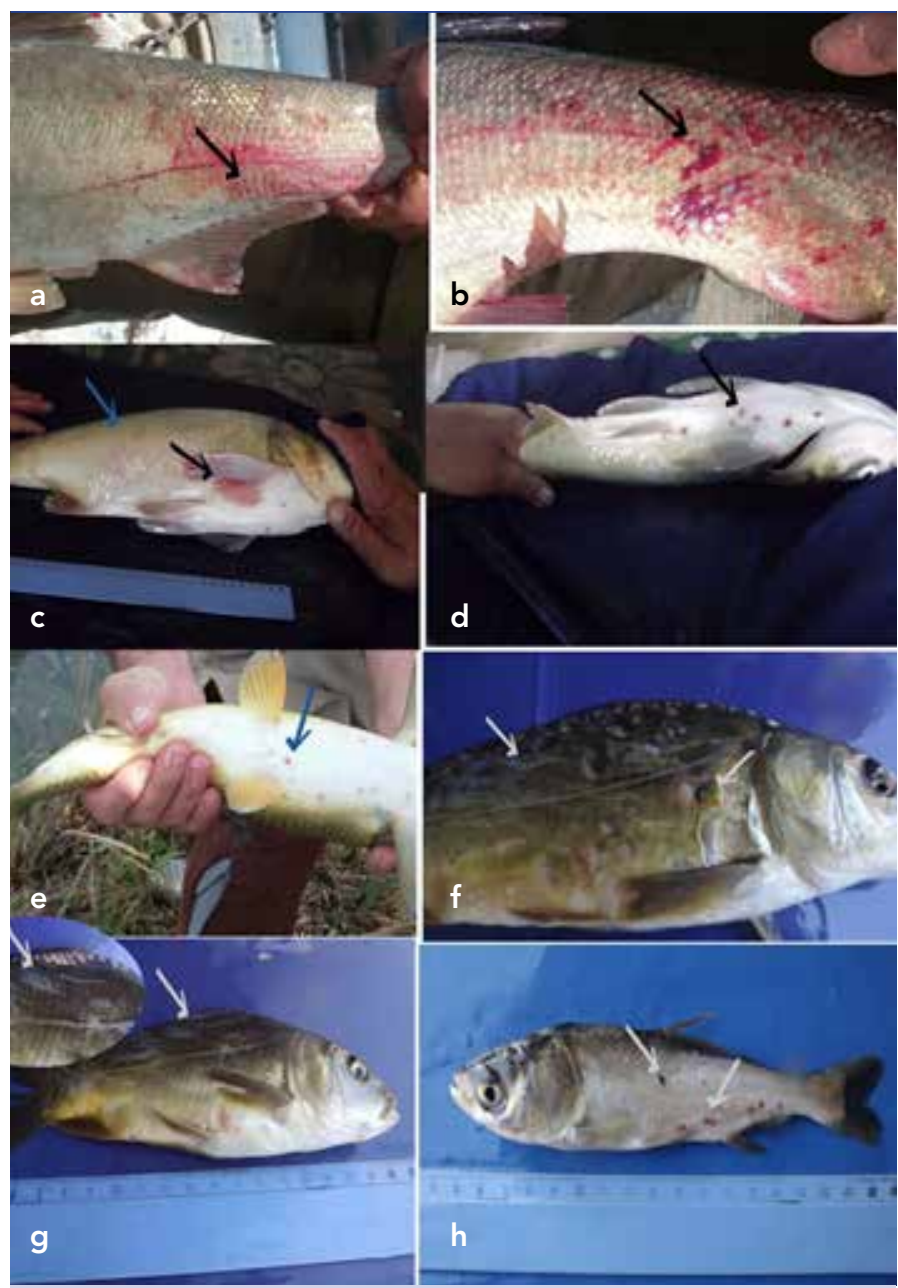

Figure 1. a-h. Clinical abnormalities of leechiosis affected cyprinids brooders and fingerlings. The infested $\mathrm{H}$. molitrix brooders showed severe hemorrhages at caudal peduncle and anal fin $(a, b)$. Also, there were inflamed pectoral fins and red inflamed marks at body sides (c) and ventral body surface of $\mathrm{H}$. molitrix brooders (d) and C. idella brooders (e). There were dark contracted worm with white marks on the skin of $C$. carpio fingerling $(f, g)$. Also, the infested $\mathrm{H}$. molitrix fingerlings showed dark contracted worm with red inflamed marks on the skin (h). 
tral body surface of $\mathrm{H}$. molitrix and $\mathrm{C}$. idella brooders (Figure $1 \mathrm{~d}, \mathrm{e})$. On the other hand, the infested C. carpio fingerlings showed dark contracted worm attached to the skin with white marks (Figure 1f, g). Also, the infested $\mathrm{H}$. molitrix fingerlings showed dark contracted worm and red inflamed marks on the skin (Figure $1 \mathrm{~h}$ ).

The prevalence of suspected leechiosis among $H$. molitrix, C. idella and C. carpio brooders was $63.33 \%, 10 \%$ and $0 \%$ respectively, while, the prevalence among $\mathrm{H}$. molitrix, $\mathrm{C}$. idella and C. carpio fingerlings was $10 \%, 5 \%$ and $70 \%$ respectively.

According to the general characters of the parasite and the identification key, it was identified as Hemiclepsis marginata (Figure 2), where, the body is not divided into distinct anterior

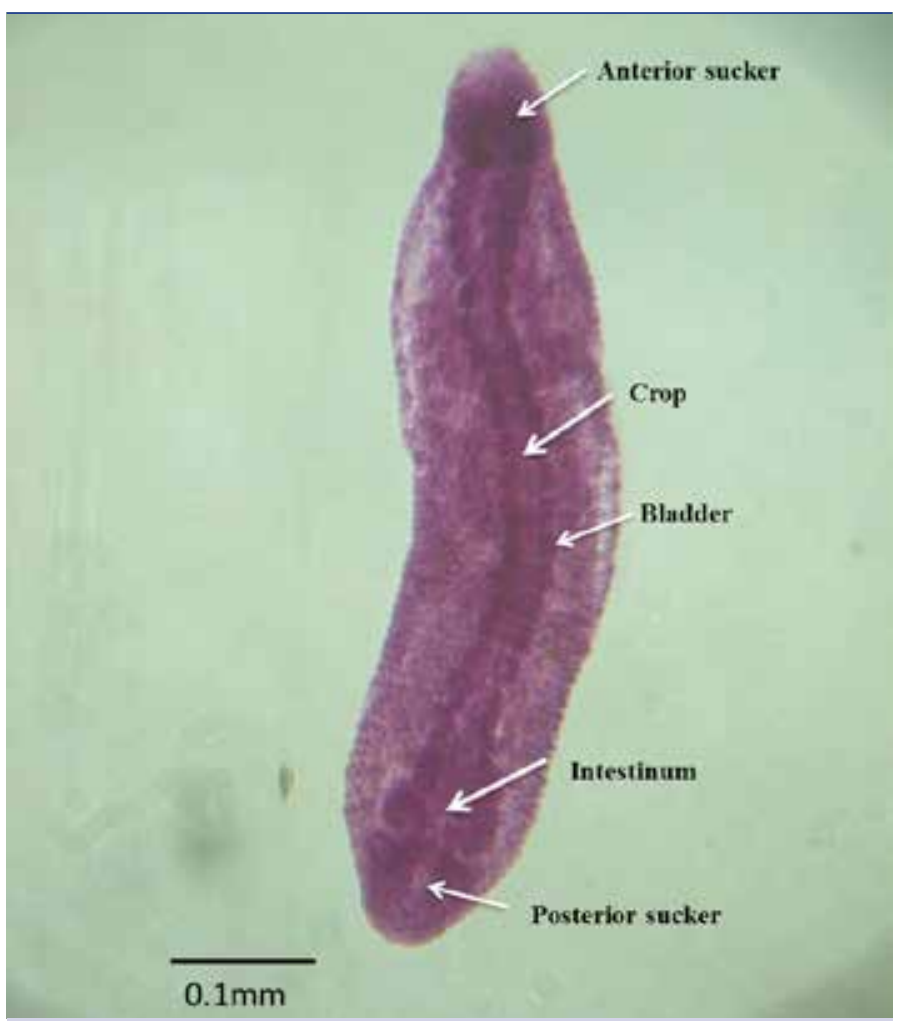

Figure 2. Hemiclepsis marginata according to the identification key of Muller (1774). Scale bar $0.1 \mathrm{~mm}$ and posterior regions and the head is much narrower than the body. There was anterior sucker at head region and posterior sucker at the most posterior part of the body (Figure 2).

\section{The Impact of Leechiosis on Semi-Artificial Spawning} Performance of $\boldsymbol{H}$. molitrix Brooders

The weight of eggs, percentage of fertility and hatching of $\mathrm{H}$. molitrix brooders was significantly affected by leechiosis. In infested $H$. molitrix brooders, the weight of eggs was $0.6,0.9$ and $1 \mathrm{~kg}$, while, it was 70, 60 and $65 \mathrm{~kg}$ in apparently healthy ones during 3 semiartificial spawning processes respectively. On the other hand, the percentage of fertility and hatching in infested $\mathrm{H}$. molitrix brooders was $60 \% \& 55 \%, 50 \% \& 45 \%$ and $60 \%$ \& $55 \%$, while, it was $75 \%$ \& $70 \%, 85 \% \& 80 \%$ and $85 \% \& 80 \%$ in apparently healthy ones during 3 semi-artificial spawning processes respectively (Table 1).

\section{The Effect of Leechiosis on Hematological Parameters of $H$. molitrix Brooders}

The infested males and females $H$. molitrix brooders showed significant reduction in red cell count, $\mathrm{Hb}$ concentration, PCV $\%, \mathrm{MCV}$ and $\mathrm{MCHC}$ values when compared to control (Table 2). Regarding the leukogram, there was a significant increase in the total leukocytic count in both infested males and females. This leukocytosis is accompanied with significant decrease in lymphocytes number and increase in the count of heterophils. Eosinophil count showed significant increase in infested females when compared with control (Table 2).

\section{Stress Indicators (Total Antioxidant Enzymes and MDA) Levels in Serum of Semi-Artificially Semi-Artificially H. molitrix Brooders}

The total antioxidant enzymes in infested males and females $H$. molitrix brooders were significantly decreased when compared to apparently healthy ones (Table 3). Oppositely, the level of MDA was significantly increased in infested males and females H. molitrix brooders than apparently healthy ones (Table 3).

\section{Control of Leechiosis Among C. carpio Fingerlings by Trichlorfon} The $\mathrm{LC}_{50}$ of trichlorfon was $61 \mathrm{mg} / \mathrm{L}$ (Table 4), where, the largest dose which killed all fish was $90 \mathrm{mg} / \mathrm{L}$ and the summation $(\Sigma)$ of Ax B was 290.

Regarding the control of leechiosis among $C$. carpio fingerlings by trichlorfon, it was found that the severity of leechiosis clinical

Table 1. The impact of leechiosis on semi-artificially spawned $H$. molitrix brooders (mean $M \pm S E$ )

\begin{tabular}{|c|c|c|c|c|c|c|c|}
\hline \multirow{2}{*}{$\begin{array}{l}\text { Semi-Artificial } \\
\text { spawning } \\
\text { process }\end{array}$} & \multirow{2}{*}{$\begin{array}{c}\text { Weight } \\
\text { of } \\
\text { Brooders }\end{array}$} & \multicolumn{2}{|c|}{ Weight of eggs (kg) } & \multicolumn{2}{|c|}{$\%$ of fertility } & \multicolumn{2}{|c|}{$\%$ of hatching } \\
\hline & & Infested & Apparently healthy & Infested & Apparently healthy & Infested & Apparently healthy \\
\hline $1^{\text {st }}$ & $2-5 \mathrm{~kg}$ & 0.6 & 70 & 60 & 75 & 55 & 70 \\
\hline $2^{\text {nd }}$ & & 0.9 & 60 & 50 & 85 & 45 & 80 \\
\hline \multirow[t]{2}{*}{$3^{\text {rd }}$} & & 1 & 65 & 60 & 85 & 55 & 80 \\
\hline & & $\begin{array}{c}{ }^{* \star} \mathrm{M}=0.83 \\
\mathrm{SE} \pm 0.12\end{array}$ & $\begin{array}{c}M=65 \\
S E \pm 2.89\end{array}$ & $\begin{array}{c}{ }^{*} \mathrm{M}=56.67 \\
\mathrm{SE} \pm 3.33\end{array}$ & $\begin{array}{l}M=83.33 \\
S E \pm 1.67\end{array}$ & $\begin{array}{c}{ }^{*} \mathrm{M}=51.67 \\
\mathrm{SE} \pm 3.33\end{array}$ & $\begin{array}{l}M=78.3 \\
S E \pm 1.66\end{array}$ \\
\hline
\end{tabular}


abnormalities was reduced to $80 \%$ in treated group at $7^{\text {th }}$ day post first trichlorfon application comparing with $10 \%$ reduction in control positive group. Also, the reduction of the disease clinical abnormalities at $7^{\text {th }}$ day post second trichlorfon applications was $100 \%$ in treated group comparing with $30 \%$ reduction in control positive group. There were no clinical abnormalities in control negative group.

\section{The Effect of Trichlorfon on Hematological Parameters of Trichlorfon Treated C. varpio Fingerlings}

The erythrocyte count, $\mathrm{Hb}$ concentrations and PCV values of the infested C. carpio fingerlings group were decreased significantly when compared to control negative(apparently healthy) one. The group of trichlorfon treated $C$. carpio fingerlings showed significantly increased values of $\mathrm{Hb}$ conc. and PCV percentage

Table 2. Hematological changes of leechiosis infested $H$. molitrix brooders (mean \pm SE).

\begin{tabular}{|c|c|c|c|c|}
\hline & \multicolumn{2}{|c|}{ Males } & \multicolumn{2}{|c|}{ Females } \\
\hline & Control & Infested & Control & Infested \\
\hline $\operatorname{RBCs}\left(10^{6}\right)$ & $5.78 \pm 0.22$ & $4.9 \pm 0.26^{\star}$ & $5.83 \pm 0.16$ & $4.73 \pm 0.22^{\star \star}$ \\
\hline PCV\% & $38.5 \pm 0.65$ & $28.00 \pm 0.10^{\star \star}$ & $36.25 \pm 0.63$ & $27.00 \pm 0.11^{\star \star \star}$ \\
\hline $\mathrm{Hb}$ (g/dL) & $6.24 \pm 0.14$ & $3.86 \pm 0.13^{\star \star \star \star}$ & $5.68 \pm 0.21$ & $3.67 \pm 0.13^{\star \star \star}$ \\
\hline MCV (fL) & $65.81 \pm 2.7$ & $57.38 \pm 1.9^{*}$ & $62.30 \pm 2.1$ & $54.40 \pm 1.24^{\star}$ \\
\hline $\mathrm{MCHC}(\%)$ & $16.36 \pm 0.28$ & $13.83 \pm 0.68^{\star}$ & $15.65 \pm 0.36$ & $13.61 \pm 0.48^{\star}$ \\
\hline WBCS $\left(10^{3}\right)$ & $26.00 \pm 1.1$ & $32.75 \pm 1.03^{\star \star}$ & $25.50 \pm 1.32$ & $34.00 \pm 0.91^{\star \star}$ \\
\hline $\begin{array}{l}\text { Lymphocyte } \\
\left(10^{3}\right)\end{array}$ & $17.19 \pm 0.41$ & $13.9 \pm 1.67^{\star}$ & $15.10 \pm 0.80$ & $11.51 \pm 0.31^{\star \star \star}$ \\
\hline $\begin{array}{l}\text { Heterophil } \\
\left(10^{3}\right)\end{array}$ & $8.42 \pm 0.68$ & $18.45 \pm 0.78^{\star \star \star}$ & $9.77 \pm 0.62$ & $21.39 \pm 1.20^{\star \star}$ \\
\hline $\begin{array}{l}\text { Monocyte } \\
\left(10^{3}\right)\end{array}$ & $0.26 \pm 0.01$ & $0.17 \pm 0.10$ & $0.45 \pm 0.13$ & $0.51 \pm 0.10$ \\
\hline $\begin{array}{l}\text { Eosinophils } \\
\left(10^{3}\right)\end{array}$ & $0.13 \pm 0.08$ & $0.24 \pm 0.1$ & $0.20 \pm 0.06$ & $0.59 \pm 0.10^{\star \star}$ \\
\hline \multicolumn{5}{|c|}{$\begin{array}{l}\text { RBCs: red blood cells; PCV: packed cell volume; Hb: hemoglobin; MCV: mean } \\
\text { corpuscular volume; MCHC: mean corpuscular hemoglobin concentration; WBCs: white } \\
\text { blood cells }\end{array}$} \\
\hline & r from control gro & In + $_{n}$ valu & $5,{ }^{* *} p<0.01$, and & 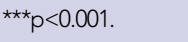 \\
\hline
\end{tabular}

Table 3. The total antioxidant and MDA in serum of semiartificially spawned $H$. molitrix brooders as stress indicators

\begin{tabular}{|c|c|c|c|c|}
\hline & \multicolumn{2}{|c|}{ Males } & \multicolumn{2}{|c|}{ Females } \\
\hline & Control & Infested & Control & Infested \\
\hline $\begin{array}{l}\text { Total antioxidants } \\
(\mathrm{mM} / \mathrm{L})\end{array}$ & $3.36 \pm 0.57$ & $1.28 \pm 0.05^{\star}$ & $4.8 \pm 0.51$ & $2.9 \pm 0.12^{\star}$ \\
\hline "MDA (nmol/mL) & $2.16 \pm 0.47$ & $6.29 \pm 0.15^{\star \star}$ & $2.78 \pm 0.32$ & $4.88 \pm 0.26^{\star *}$ \\
\hline \multicolumn{5}{|c|}{ "MDA: malondialdehyde } \\
\hline
\end{tabular}

Table 4. The $24 \mathrm{hrs}$ median lethal concentration (LC50) of trichlorfon among $C$. carpio fingerlings

\begin{tabular}{|c|c|c|c|c|c|c|}
\hline Fish groups & $\begin{array}{c}\text { No. of } \\
\text { fish/group }\end{array}$ & $\begin{array}{c}\text { Trichlorfon } \\
\text { dose } \\
\text { (mg/L) }\end{array}$ & $\begin{array}{l}\text { No. of } \\
\text { dead fish }\end{array}$ & $A$ & $B$ & $(A \times B)$ \\
\hline 1 (control) & 10 & 0 & 0 & 0 & 0 & 0 \\
\hline 2 & 10 & 10 & 0 & 0 & 0 & 0 \\
\hline 3 & 10 & 20 & 0 & 0 & 10 & 0 \\
\hline 4 & 10 & 30 & 0 & 0 & 10 & 0 \\
\hline 5 & 10 & 40 & 1 & 0.5 & 10 & 5 \\
\hline 6 & 10 & 50 & 3 & 2 & 10 & 20 \\
\hline 7 & 10 & 60 & 5 & 4 & 10 & 40 \\
\hline 8 & 10 & 70 & 7 & 6 & 10 & 60 \\
\hline 9 & 10 & 80 & 8 & 7.5 & 10 & 75 \\
\hline 10 & 10 & 90 & 10 & 9 & 10 & 90 \\
\hline $\begin{array}{l}24 \text { hours } L C_{50}=1 \\
A=\text { Mean of dea } \\
B=\text { Dose differer } \\
\Sigma(A \times B)=\text { summa } \\
24 \text { hours } L C_{50} \text { of }\end{array}$ & $\begin{array}{l}\text { argest dose whic } \\
\text { ce between } 2 \text { sish }(A \times B) n=1 \\
\text { trichlorfon }=90-2\end{array}$ & $\begin{array}{l}\text { ich killed all fis } \\
2 \text { successive d } \\
\text { uccessive dos } \\
\text { No. of fish } / \mathrm{grc} \\
290 / 10=61 \mathrm{mg}\end{array}$ & $\begin{array}{l}\text { sh }-\Sigma(A \times B) / n \\
\text { lose } \\
\text { ses } \\
\text { oup. } \\
g / L\end{array}$ & & & \\
\hline
\end{tabular}

Table 5. The effect of trichlorfon on hematological parameters of treated $C$. carpio fingerlings (mean \pm SE)

\begin{tabular}{|c|c|c|c|}
\hline $\begin{array}{l}\text { Blood } \\
\text { parameters }\end{array}$ & $\begin{array}{l}\text { *Negative } \\
\text { control } \\
\text { (apparently } \\
\text { healthy) }\end{array}$ & $\begin{array}{c}\text { **Infested } \\
\text { (positive } \\
\text { control) }\end{array}$ & $\begin{array}{l}\text { Trichlorfon } \\
\text { treated }\end{array}$ \\
\hline $\mathrm{RBCs}\left(10^{6}\right)$ & $4.85 \pm 0.26$ & $3.75 \pm 0.28$ a & $4.47 \pm 0.28$ \\
\hline PCV \% & $30.25 \pm 2.29$ & $21.75 \pm 0.63^{a}$ & $29.25 \pm 1.79 b$ \\
\hline $\mathrm{Hb}(\mathrm{g} / \mathrm{dL})$ & $4.92 \pm 0.21$ & $3.62 \pm 0.11^{a}$ & $4.7 \pm 0.28^{b}$ \\
\hline $\mathrm{MCV}(\mathrm{fL})$ & $68.07 \pm 4.9$ & $58.77 \pm 4.1$ & $60.64 \pm 3.01$ \\
\hline $\mathrm{MCHC}(\%)$ & $16.56 \pm 1.5$ & $16.64 \pm 0.34$ & $16.41 \pm 1.79$ \\
\hline WBCS (103) & $23.25 \pm 1.11$ & $35.00 \pm 1.29$ a & $28.75 \pm 1.5^{\mathrm{ab}}$ \\
\hline Lymphocyte $\left(10^{3}\right)$ & $13.75 \pm 0.51$ & $11.85 \pm 0.45^{a}$ & $14.42 \pm 0.21 b$ \\
\hline Heterophil $\left(10^{3}\right)$ & $8.86 \pm 0.43$ & $21.46 \pm 0.98$ a & $13.24 \pm 1.2 \mathrm{ab}$ \\
\hline Monocyte $\left(10^{3}\right)$ & $0.88 \pm 0.16$ & $0.98 \pm 0.19$ & $0.65 \pm 0.20$ \\
\hline Eosinophils $\left(10^{3}\right)$ & $0.38 \pm 0.08$ & $1.08 \pm 0.03^{a}$ & $0.40 \pm 0.1^{b}$ \\
\hline \multicolumn{4}{|c|}{$\begin{array}{l}\text { The data are given as means } \pm \text { SEM with dissimilar superscript letters } \\
\text { (significantly differ at } p<0.05 \text { ): (a) letter is significantly differing from control } \\
\text { value, and (b) letter is significantly differing from infested group }\end{array}$} \\
\hline \multicolumn{4}{|c|}{$\begin{array}{l}\text { *Negative control: the infested fish group which received no treatment by } \\
\text { trichlorfon }\end{array}$} \\
\hline \multicolumn{4}{|c|}{$\begin{array}{l}\text { **Positive control: the apparently healthy fish group which received no } \\
\text { treatment by trichlorfon }\end{array}$} \\
\hline
\end{tabular}


comparing with control positive (infested) one. No significant difference was found in the red blood cell counts, $\mathrm{Hb}$ concentration and PCV percentage between control negative group and those treated with trichlorfon (Table 5). The values of MCV and $\mathrm{MCHC}$ showed no significant changes between the control positive groups and control negative one.

Significant increase in total leukocyte; heterophil and eosinophil counts were observed, as well as decreased number of lymphocytes in control positive group compared with control negative one. On the other hand, the WBC and heterophil counts dropped significantly after trichlorfon treatment but remained higher than the control. Lymphocyte count was remarkably increased and eosinophil count was significantly decreased in fish treated with trichlorfon comparing to control positive (Table 5).

\section{Field Control of Leechiosis Among $H$. molitrix Brooders and C. carpio Fingerlings}

The severity of leechiosis clinical abnormalities was reduced to $60 \%$ and $65 \%$ in treated $H$. molitrix brooders and C. carpio fingerlings respectively at $7^{\text {th }}$ day post first trichlorfon application. Regarding, the reduction of the severity of leechiosis clinical abnormalities at $7^{\text {th }}$ day post second trichlorfon applications was $100 \%$ in both $H$. molitrix brooders and C. carpio fingerlings.

Leechiosis may affect fish health through tissue damage, inflammatory reactions, hemorrhages, anemia, ulcerations and osmoregulatory failures (Burreson, 2006; Koyun et al., 2015). Also, leechiosis may cause mortalities in fish hatcheries (Woo, 2006) resulted in economic losses.

Although, there are some researches dealing with leechiosis in hatchery reared fish (Woo, 2006) but, there are no studies concerned with the impact of leechiosis on artificial spawning performance of hatchery reared cyprinids. In Abo-Saleh fish hatchery, Beni-Suef, Egypt, there was a complaint of decreasing artificial spawning performance of $\mathrm{H}$. molitrix brooders. As understood during the in situ investigation, the hatchery filters were replaced with a lower quality set. Moreover, clinically examined cyprinid brooders and fingerlings showed macroscopic dark contracted worm on the skin with red to white marks.

Regarding the prevalence of suspected leechiosis among hatchery reared cyprinid brooders and fingerlings, it was found that in brooders the highest prevalence recorded in $H$. molitrix (63.33\%), while, in fingerlings, the highest prevalence was found in C. carpio (70\%).

For confirmation of the leech suspicion, carful microscopic examination of fresh leech was done before fixation as distinguishing between various species of leeches is not easy (Woo, 2006). Based on the external characters and the identification key of leech (Muller, 1774) the identified leech was Hemiclepsis marginata (Figure 2). Many studies reported that Hemiclepsis marginata was harmful for cyprinids as it is feeding on blood and acts as vector for viral and bacterial pathogens between cyprinid species (Hoole et al., 2001; Woo, 2006; Maria et al., 2016). Hemiclepsis marginata belongs to family Glossiphoniidae which found in freshwater habitats and act as environmental stress indi- cator due to its relative abundance in certain freshwater habitats (Grantham and Hann, 1994).

Regarding clinical abnormalities of leechiosis affected cyprinids, Hoole et al., (2001) recorded similar signs as previously mentioned in our study.

Concerning the prevalence of leechiosis among hatchery reared cyprinid brooders and fingerlings, Öktener et al., (2007) found that the highest prevalence of leechiosis was in C. carpio (8.8\%), while, Bielecki et al., (2008) reported that the highest prevalence of leechiosis was found in Champsocephalus wilsoni (9.9\%) of Antarctic fish of the family Channichthyidae. These variations may be attributed to the difference of leech species, fish species and environmental factors. In Abo-Saleh fish hatchery, the appearance of leechiosis was due to use of low quality filters, additionally; the highest leechiosis prevalence among $H$. molitrix brooders and $C$. carpio fingerlings was contributed to absence of screen on their pond water inlets. These findings were supported by Woo (2006) who mentioned that leeches invaded the hatchery through the freshwater supply from a nearby stream and attacked the fish.

In this study, leechiosis had a negative effect on semi-artificial spawning performance of $\mathrm{H}$. molitrix brooders, as, there was significant reduction in the weight of eggs, fertility and hatching percentage of infested $H$. molitrix brooders comparing with apparently healthy ones (Table 1). These findings may be related to microcytic hypochromic anemia (Table 2) and/or stress effect caused by leechiosis (Table 3). Stressed cyprinid brooders showed significant decrease of total antioxidant enzymes and increase of MDA level (Table 3). These findings were matched with Dautremepuits et al. (2003) and Akar (2011) who's confirmed that stress due to parasitic diseases may affect the fecundity of brood stocks and causing infertility. Moreover, http://www.ceh.ac.uk/StaffWebPages/ TomPottinger mentioned that exposure of hatchery reared brooders to stress factors during the reproductive period can delay ovulation and reduce egg size in female, reduce sperm count in males and cause resorption of the eggs in the ovary.

Furthermore, it was found that both infested male and female $\mathrm{H}$. molitrix brooders showed decrease red cell count, $\mathrm{Hb}$ conc. and $\mathrm{PCV} \%$. The reduction of MCV and MCHC values indicated presence of microcytic hypochromic anemia (Table 2). These findings may be due to hemorrhages (Campbell and Ellis, 2007) and blood loss caused by blood sucking leech. Marked hemorrhage often results in microcytic anemia because regenerating immature erythrocytes are smaller than mature one and represent the majority of the circulating erythrocytes. Moreover, when severe or chronic blood loss occurs, the net loss of iron may result in microcytic hypochromic anemia (Clauss et al., 2008).

The leukocytosis, lymphopenia and heterophilia observed in the infested brooders can suggest stress condition. The elevated eosinophil count in female brooders may be suggested an inflammatory response associated with the parasitic infection (Clauss et al., 2008).

Oxidative stress and lipid peroxidation associated with parasitic diseases in fish may be having a possible role in their pathogen- 
esis (Marcogliese et al., 2005; Mozhdeganloo and Heidarpour, 2014). In this study, the serum activity of total antioxidant enzymes was significantly lower in infested $H$. molitrix brooders than those of healthy one, indicating depletion of antioxidant defenses due to oxidative stress. Also, the level of MDA in serum was higher in infested fish comparing to control (Table 3). Malondialdehyde is an end product in the lipid peroxidation process and its accumulation in biological fluids or tissues is indicative of the extent of oxidative stress and lipid peroxidation (Halliwell and Chirico, 1993). These results were confirmed by Dautremepuits et al., (2003) and Stumbo et al., (2012) whose proved that the antioxidant enzymatic activities were decreased in carp and fathead minnows parasitized by Ptychobothrium sp. and cercaria of two species of trematodes respectively. Also, Mozhdeganloo and Heidarpour, (2014) proved that dactylogyrosis caused severe oxidative stress and higher MDA level in infested goldfish than non- parasitized ones.

For leechiosis control, trichlorfon was safe and effective as the $\mathrm{LC}_{50}$ (Table 4) was far from the field treatment dose. Also, the leechiosis clinical abnormalities were completely disappeared from the laboratory and hatchery trichlorfon treated $\mathrm{C}$. carpio fingerlings and hatchery trichlorfon treated $\mathrm{H}$. molitrix brooders. These findings were supported by Morrison et al., (1993) who proved that trichlorfon had the superior leechiosis control than other chemicals. In addition, trichlorfon succeeded in returning the hematological parameters of laboratory treated $C$. carpio fingerlings to normal, while, the infested non-treated $C$. carpio fingerlings showed normocytic normochromic anemia. Corrêa et al., (2016) mentioned that normocytic normochromic anemia is characterized by decrease in the RBCs count, PCV \% and $\mathrm{Hb}$ concentration as detected in this investigation. The returning of hematological parameters of trichlorfon treated C. carpio fingerlings to normal may be due to lethal effects of trichlorfon on leech and subsequently relieving of its pathological effects.

\section{CONCLUSIONS}

Leechiosis affect fish health of hatchery reared cyprinid brooders and fingerlings (affect semi-artificial spawning performance and hematological parameters) and its harmful effect can be mitigated by trichlorfon.

\section{ACKNOWLEDGMENT}

We would like to thank manager of Abo-Saleh fish hatchery, Beni-Suef, Egypt for his cooperation for fish samples collection. Also, we would like to thank Prof. Dr. Olfat Anter, professor of parasitology, faculty of veterinary medicine, Cairo University for her effort for leech identification. Great thanks to Scientific Research Developing Unit, Beni-Suef University, Egypt for its financial support.

\section{REFERENCES}

Akar, M.A. (2011). Effects of stress on spawners reproductive performance in female Grass Carp (Ctenopharyngodon idella). Journal of the Arabian Aquaculture Society, 6, 172-180.
Behrens, B., Kerber, J. (1953). Archive of Experimental Pathology and Pharmacology. 177

Bielecki, A., Rokicka, M., Ropelewska, E., Dziekońska-Rynko, J. (2008) Leeches (Hirudinida: Piscicolidae) - parasites of Antarctic fish from Channichthyidae family. Wiadomooeci Parazytologiczne, 54, 345348.

Burreson, E. M. (2006). Phylum Annelida: Hirudinea as Vectors and Disease Agents. In: Fish Diseases and Disorders: Protozoan and Metazoan Infections, Woo, P.T.K. (Ed.). $2^{\text {nd }}$ Ed., CAB International, Oxon, UK. ISBN: 9780085199011, pp: 566-591. [CrossRef]

Canadian Council of Ministers of the Environment, (2012). Canadian water quality guidelines for the protection of aquatic life: Trichlorfon. In: Canadian environmental quality guidelines, 1999, Canadian Council of Ministers of the Environment, Winnipeg.

Campbell, T., Ellis C. (2007). Avian and exotic animal hematology and cytology. New York: Wiley-Blackwell.

Clauss, T.M., Dove, A.M., Arnold, J.E. (2008). Hematologic Disorders of Fish. Veterinary Clinics of North America: Exotic Animal Practice, 11: 445-462. [CrossRef]

Corrêa, L., Tavares-Dias, M., Ceccarelli, P., Adriano, E. (2016). Hematological alterations in Astyanax altiparanae (Characidade) caused by Lernaea cyprinacea (Copepoda: Lernaeidae). Diseases Aquatic Organisms, 120, 77-81. [CrossRef]

Dacie, J.V., Lewis, S.M. (1966). Practical Haematology. 3rd ed. 435 pp. London: J. \& A. Churchill.

Dautremepuits, C., Betoulle, S., Vernet, G. (2003). Stimulation of antioxidant enzymes levels in carp (Cyprinus carpio L.) infected by Ptychobothrium sp. (Cestoda). Fish \& Shellfish Immunology. 15: 467-471. https://doi.org/10.1016/S1050-4648(03)00007-X [CrossRef]

Ellender, V.R., Weyl, O.L.F. (2014). A review of current knowledge, risk and ecological impacts associated with non-native fish introductions in South African. Aquatic Invasions, 9, 117-132. [CrossRef]

Feldman, B.V., Zinkl, J.G., Jain, N.C. (2000). Schalm's Veterinary Hematology. 5 Eds. Lea and Fibiger, Philadelphia USA.

Gheyas, A.A., Mollah, A.F., Islam, M.S., Hussani, M.G. (2001). Coldshockinduction of diploid gynogenesis in stinging catfish, Heteropneustes fossilis. Journal of applied Aquaculture, 11, 227-240. [CrossRef]

Grantham, B.A., Hann, B.J. (1994). Leeches (Annelida: Hirudinea) in the experimental lakes area, Northwestern Ontario, Canada: Patterns of species composition in relation to environment. Canadian Journal of Fish Aquatic Science 5, 1600-1907. [CrossRef]

Halliwell, B., Chirico, S. (1993). Lipid peroxidation: its mechanism, measurement, and significance. Am J Clin Nutr 57, 715-725. [CrossRef]

Hoole, D., Bucke, D., Burgess, P., Wellby, I. (2001). Diseases of carp and other cyprinid fishes text book. Wiley-Blackwell. ISBN: 978-0-85238252-3. [CrossRef]

Lopes, R.B., Paraiba, L.C., Ceccarelli, P.S., Valdemar, L.T. (2006). Bioconcentration of trichlorfon insecticide in pacu (Piaractus mesopotamicus). Chemosphere, 64, 56-62. [CrossRef]

Koyun, M., Tepe, Y., Mart, A. (2015). First Record of Piscicola geometra (Annelida, Hirudinea) on some Species of Cyprinidae from Euphrates-Tigris Basin in Turkey. Journal of Fisheries and Aquatic Science, 10, 575-580. [CrossRef]

Marcogliese, D.J., Brambilla, L.G., Gagne, F., Gendron, A.D. (2005). Joint effects of parasitism and pollution on oxidative stress biomarkers in yellow perch Perca flavescens. Aquatic Organism 63, 77-84. [CrossRef]

Maria, M.C.O., Joana, I.E.S.R., Fernando, M.D.B. (2016). Practical nations on fish health and production book. Bentham Science Publisher.

Morrison, J.R., Steven, R.F., Wilmer, A.R. (1993). Control of an infestation of a fish leech (Myzobdella lugubris) on catfishes in tanks and earthen ponds. Aquatic Animal Health, 5, 110-114. [CrossRef]

Mozhdeganloo, Z., Heidarpour, M. (2014). Oxidative stress in the gill tissues of goldfishes (Carassius auratus) parasitized by Dactylogyrus 
spp. Parasitology, 38, 269-272. [CrossRef]

Müller, O.F. (1774). Vermium terrestrium·et fluviatilium. Heineck \& Faber, 1, 1-214.

Noga, E.J. (2010). Fish disease: Diagnosis and treatment. Copyright Mosby-year Book, Watsworth publishing, $2^{\text {nd }}$ ed., Co., USA. [CrossRef]

Öktener, A., Trilles, J.P., Leonardos, I. (2007). Five Ectoparasites from Turkish Fish. Türkiye Parazitoloji Dergisi, 31, 154-157.

Ohkawa, H., Ohishi, N., Yagi, K. (1979). Assay for lipid peroxides in animal tissues by thiobarbituric acid reaction. Analytical Biochemistry, 95, 351-358. [CrossRef]

Powell, E.N., Bochenek, E.A., Klinck J.M., Hofmann, E.E. (2002). Influence of food quality and quantity on the growth and development of
Crassostrea gigas larvae: a modeling approach. Aquaculture, 210 89-117. [CrossRef]

Pritchard, M.H., Kruse, G.O. (1982). The collection and preservation of animal parasites. Technical Bulletin No. 1. The Harold W. Manter Laboratory, University of Nebraska Press. Pp.141.

Stumbo, A.D., Goater, C.P., Hontela, A. (2012). Parasite-induced oxidative stress in liver tissue of fathead minnows exposed to trematode cercariae. Parasitology, 139, 1666-1671. [CrossRef]

Wasser, S.K., Sewalland, G., Soules, A.D. (1993). Psychosocial stress as a cause of infertility. J Reprod Fertil, 59, 685-689.

Woo, P.T.K. (2006). Fish Diseases and Disorders: Protozoan and Metazoan Infections, Hirudinea as Vectors and Disease Agents. $2^{\text {nd }}$ Ed., CAB International, Oxon, UK., ISBN: 9780085199011, pp. 566-591. 